\title{
An Investigation into the Fundamental Drivers of Pricing of Residential Mortgage Products - A Risk Pricing Viewpoint
}

\author{
Dr Harry M. Karamujic, (University of Melbourne, Australia)
}

\begin{abstract}
Residential mortgage products (also known as home loans) pricing has been long understood to be something of a 'dark art', requiring judgment and experience, rather than being an exact science. In the last decade, a lot has changed in this field and more and more lenders, primarily the larger lenders, are increasingly looking to make their pricing as exact as possible. Even so, inadequate pricing of residential mortgage products (in particular its substandard risk pricing) has been seen as one of major causes of the global financial crisis (GFC) and subsequent spectacular banking collapses. The underlying theme of the paper is to exhibit how contemporary lenders, in practice, price their residential mortgage products. While discussing elements of the pricing calculation particular attention was given to the exposition of how contemporary lenders price risks involved in providing home loans. Because of the importance of Basel capital accords to how financial institutions assess and quantify their risks, the paper provides an overview of Basel capital accords. The author envisages that the paper will (i) help enhance comprehension of the underlying elements of the pricing calculation and the ways in which these elements relate to each other, (ii) scrutinize how contemporary lenders identify and quantify risks and (iii) improve consciousness of future changes in interest rates.
\end{abstract}

Keywords: Home loan pricing, Home loan products, Basel capital accords, Cost plus pricing technique, Risk quantification, Risk pricing, Provisioning

\section{Introduction}

The Australian home loan industry is characterised by a very homogenous products offering, a strong risk-pricing discipline, a highly concentrated industry structure, and products (home loans) that are almost fully commoditised ${ }^{1}$. In 1997, Beyond Commodity Status, the Council on Financial Competition's syndicated study, identified the following three hallmarks of commoditisation in the retail financial services industry leading to rapid industry consolidation: (i) increasing price elasticity of individual borrowers, (ii) pressure on profit margins across the core product set, and (iii) strategic emphasis on cost reduction.

When discussing pricing, it is important to have in mind that pricing is only one element of the marketing mix and, as such, must be assessed as part of a wider picture. The other marketing mix elements are distribution, process, product and promotion. Activities such as the introduction of a new product or new distribution channel are generally very costly, and the impact of these types of changes will generally take some time to start making a difference. In contrast, the impact of pricing-related initiatives is, typically, almost instantaneous. For example, a change in price for fixed rate home loans (FRHLs) would impact on all new home loan sales, while a change in price for variable rate home loans would have an impact on the whole portfolio. Of course, in a real life situation, all of the marketing mix functions need to work together cooperatively i.e. pricing without promotion and adequate product mix and process cannot produce much in isolation. Nevertheless, relative to other less competitive and homogenous industries, home loan borrowers are typically more price sensitive, which makes pricing more relevant and more often used by lenders as a driving force for various marketing initiatives.

\footnotetext{
${ }^{1}$ For more on home loan products see Karamujic (2009), Chapter 5.
} 
Overall, home loan pricing entails pricing interest rates and fees ${ }^{2}$. Fee pricing, in general, is much more static and by and large significantly smaller contributor to the overall price. Consequently, the focus of this paper will be on home loan interest rates pricing.

More precisely, the paper aims to show how lenders price their home loans i.e. determine home loan interest rates. While discussing elements of the pricing calculation, particular attention was given to how contemporary lenders identify and quantify risks. The author believes that with a bit of adjustment a very similar approach can be adopted by other disciplines (such as property), which currently employ significantly less sophisticated methods of risk assessment and risk quantification. In addition to discussing home loan pricing in the next section, in Section III we will present an overview of Basel capital accords. Finally, in Section IV, the paper concludes.

\section{Home Loan Pricing}

A study conducted by Council on Financial Competition (2005) showed that the majority of lenders have, historically, devoted few or no resources to developing sound pricing models. This may be due to the fact that home loan product pricing has been long understood to be something of a 'dark art', requiring judgment and experience, rather than being an exact science. In the last decade, a lot has changed in this field and more and more lenders, primarily the larger lenders, are increasingly looking to make their pricing as exact as possible. Their attempts are supported by Council on Financial Competition (2003) research, which shows that lenders who use quantitative pricing techniques as part of their pricing process can boost their bottom-line earnings by as much as five to seven per cent. In doing so, lenders have a number of pricing techniques at their disposal:

1 Cost plus Pricing,

2 Market Pricing,

3 Promotions Pricing,

4 Tiered Pricing,

5 Timing Pricing,

6 Relationship Pricing,

7 Product Range Pricing, and

8 Premium Pricing

The cost plus pricing technique sets prices at a mark-up to a minimum price allowable. The paper focuses on cost plus pricing technique because it is the basis for all other pricing techniques i.e. all other pricing techniques discuss different margin (mark-up) combinations, which primarily depend on the lender's business goals and associated pricing strategies ${ }^{3}$.

\section{Cost-plus Pricing Technique}

The underlying motivation of the cost plus pricing technique is to determine the minimum cost of providing a home loan. On the critical side, even well constructed cost plus pricing totally ignores the question of demand and provides only an acceptable price floor. Within this framework, if we are to set the lender's margin to equal the return on equity at the lender's hurdle rate (minimum rate of return on lenders' equity acceptable to the lender), the analysis represents the break-even analysis. This analysis does not take into account factors such as the competitive landscape and a borrower's value to the lender. Nevertheless, it

\footnotetext{
${ }^{2}$ Such as transaction fees, lending fees (application and monthly service fees) and sundry fees (such as reference fees and bank cheque fees).

${ }^{3}$ For more on other pricing techniques refer to Karamujic (2009), Chapter 6.
}

Karamujic, H M (2010) 'An investigation into the fundamental drivers of pricing of residential mortgage products - A risk pricing viewpoint', Australasian Journal of Construction Economics and Building, 10 (4) 60-72 
provides a useful tool for determining product level profitability. Furthermore, the technique can be very useful in quantifying losses from products offered below cost to ensure they are being recouped elsewhere. For example, a lender may offer basic products well below the break-even point with the understanding that profits from cross-sold products will compensate for the loss. In this case, basic products serve as "loss leaders".

The basic cost plus pricing technique can be expressed as:

$$
\mathrm{H}_{\mathrm{bp}}=\mathrm{COF}+\mathrm{LLP}+\mathrm{LM}+\mathrm{COS}+\mathrm{COC}
$$

where $\mathrm{H}_{\mathrm{bp}}$ represents home loan baseline price, COF represents cost of funds, LLP represents loan loss provision charge, LM represents the lender's margin, COS represents costs of sales, and COC represents corporate overhead costs ${ }^{4}$.

\section{Cost of Funds (COF)}

An internal banking term interchangeably used with COF is the funds transfer pricing rate (FTPR). It is important to note that financial markets, although dominant, are not the only source of funds. Even though a certain proportion of lending will be funded by deposits held by the lender, for pricing purposes the lender's benchmark base yield curve (BBYC) is represented by a weighted average of funds sourced from financial markets, across the required maturity spectrum.

As its name states, the FTPR is devised, among other things, to enable meaningful funds transfer between different business units (normally between the treasury and various retailer business units, generally divided in line with the lender's borrower segmentation). The total FTPR across all defined maturity points is comprised of the BBYC and product-based risk adjustments.

$$
\mathrm{FTPR}=\mathrm{BBYC}+\mathrm{RAs}
$$

where RAs represents risk adjustments.

There may be instances, permanent or temporary, where it is necessary to make adjustments to the BBYC rate using an RA in order to transfer any risk associated with particular products or to reflect changes to the lender's overall relationship to the BBYC. RAs will normally occur for reasons of liquidity risk and optionality risk. The risk premiums generated by the risk transfer processes must be explicitly set for each product and their appropriateness must be monitored. Any RAs adopted by a lender must be supported by an appropriate analysis and approved by the lender's management prior to implementation.

To ensure the liquidity risk is adequately reflected through the fund transfer pricing process, a liquidity premium should be added to the BBYC. This is mainly influenced by the premium price in financial markets for longer-term funds ${ }^{5}$, financial markets valuation of the lender's creditworthiness ${ }^{6}$ and/or periodic changes in global capital flows ${ }^{7}$. Overall, liquidity risk can be defined as financial risk due to uncertain liquidity. Lenders' treasury departments are

\footnotetext{
${ }^{4}$ An interesting example how simplified version of the calculation can be utilised is provided by Kosonen (1997).

${ }^{5}$ There is 'natural' interest rate premium in financial markets for longer term funds.

${ }^{6}$ According to Moody (2010), its creditworthiness analysis focuses on the fundamental factors of lender's long and short term risk profile: "The foundation of Moody's methodology rests on two basic questions: (i) what is the risk to the debtholder of not receiving timely payment of principal and interest on this specific debt security?, and (ii) how does the level of risk compare with that of all other debt securities?"

${ }^{7}$ Such as the one triggered by the GFC. According to Ellis (2009) the following three are the major causes of the GFC: the misperception and mismanagement of risk; the level of interest rates; and the regulation of the financial system.
}

Karamujic, H M (2010) 'An investigation into the fundamental drivers of pricing of residential mortgage products - A risk pricing viewpoint', Australasian Journal of Construction Economics and Building, 10 (4) 60-72 
generally the ones that assess the best representative spread to the BBYC, at all maturity points, and that apply liquidity premiums across the BBYC at the appropriate points. For all products, the liquidity premium must be based on the contractual maturity as opposed to the term to the next repricing. The liquidity spread to the BBYC is normally reviewed annually.

By allowing a product-related option to be embedded in product change schedules of the lending contract, the lender faces an additional interest rate risk. The two most common examples of optionality entailed within a home loan product are: early repayment or prepayment, and repricing. An example of early repayment optionality is when a borrower has the implicit or explicit ability to terminate all or part of a "fixed term" home loan contract without incurring the payment of economic cost ${ }^{8}$. This would definitely impact on the pricing base and hence the optionality risk has to be calculated and added as an RA. A repricing optionality arises when, for example, a borrower is given the option to reprice a product (i.e. change the interest rate) at specified time intervals.

\title{
Loan Loss Provision (LLP)
}

Loan loss provisioning (LLP) is a part of the cost structure of providing a home loan that encompasses all the risks associated to providing lending products, except those related to liquidity and optionality. The lender's home loan LLP is comprised of the following two components: (i) a specific provisioning cost (risk costs associated to cycle related long-term losses) and, (ii) a general provisioning cost (related to risk costs of losses already present within the portfolio but not yet specifically identified).

As with any other cost that the lender faces, the aim is to minimise these risk costs, subject to provisioning a sufficient amount of capital that enables the lender to cover possible losses for activities that entail an element of risk. The LLP cost is typically the second largest home loan pricing calculation cost element, hence the lenders are very keen to do everything they can to reduce the cost of achieving capital adequacy (the implicit logic is that the higher the risk involved, the greater the capital backing required). Therefore, the lender's aim is optimal provisioning, which, if achieved, would contribute to total cost reduction. Equally, sub-optimal provisioning will most definitely increase total costs of operations and thus the cost of providing home loans.

Australian Prudential Regulatory Authority (APRA), as its name states, is the prudential regulator of the financial services industry in Australia. Its primary task is to oversee banks, credit unions, building societies, general insurance and reinsurance companies, life insurance companies and friendly societies. In respect of provisioning, APRA (2010) specifies that Australian Deposit Taking Institutions (ADIs) that are predominantly banks:

\begin{abstract}
"Should have sound provisioning policies to ensure asset values, earnings and capital are accurately reported. An ADI's provisioning policy should cover both specific and general provisions. Specific provisions should be raised whenever reasonable doubt exists over the recoverability of particular exposures. General provisions cover the risks which are inherent in an ADI's business but which cannot be attributed to particular exposures."
\end{abstract}

The expertise of risk quantification, relating to the LLP, is based on the concepts of expected losses (EL) and unexpected losses (UL). The notion of specific provisioning relates to the concept of ELs, while the notion of general provisioning relates to the concept of ULs. Principally, at a portfolio level, specific provisioning relates to average write-offs of the particular class of home loan being priced. For example, if home loan write-offs and post recoveries reached 10 per cent once every ten years, and were at 0 per cent for the other nine years, the gross specific provision charge should be one per cent (being a simple

\footnotetext{
${ }^{8}$ Economic cost is a fee that is charged by the lender for the early termination of the fixed rate home loan contract.
}

Karamujic, H M (2010) 'An investigation into the fundamental drivers of pricing of residential mortgage products - A risk pricing viewpoint', Australasian Journal of Construction Economics and Building, 10 (4) 60-72 
average over the observed period) of the outstanding amount (the total amount owed to the lender, at the particular point in time) for the particular class of home loans considered. On an individual (account) basis, specific provisioning is the estimate of shortfall between the face value of the debt and the estimated future cash flows, including the estimated realisable value of securities, if any. Therefore, to get the gross specific provisioning amount for an individual home loan, we need to multiply the loan-specific EL rate and the outstanding home loan amount.

There are two main methods used for specific provisioning for home loan products, namely the term product methodology and the revolving product methodology. The term product methodology applies to all home loans except line of credit (LOC) home loans. The term product methodology (ELterm) is defined as:

$$
\mathrm{EL}_{\text {term }}=\mathrm{EAD} \times \mathrm{NLR}_{\text {term }}
$$

where $E A D_{\text {term }}$ represents exposure at default and $N L R_{\text {term }}$ the net loss rate. The EAD is defined as the amount of outstanding principal, fees and interest owed at the time of default. On the other hand, the NLR is an expected cumulative net loss rate for the remainder of the loan term, and is calculated as:

$$
\mathrm{NLR}=\mathrm{GLR} \times(1-\mathrm{rcr})
$$

where GLR is a gross loss rate (estimated from the actual data and based on historically observed loss rates) and rcr is the portfolio level estimate of the recovery rate.

Contrary to the term product methodology, the revolving product methodology (EL $\left.\mathrm{L}_{\mathrm{rpm}}\right)$ applies only to LOC home loans and is calculated as follows:

$$
E L_{r p m}=E A D \times P D \times L G D,
$$

where PD represents the probability of default (the probability that a loan or group of loans will become irreversibly delinquent over a prescribe period of time) and LGD represents loss given default (percentage of exposure which will be lost after all recovery efforts, including legal expenses, time value of money and recovery expenses). The LGD is calculated as:

$$
\mathrm{LGD}=1-\mathrm{rcr} \text {. }
$$

As previously mentioned, in contrast to specific provisioning, general provisioning is derived to cover losses already present within the portfolio, but not yet specifically identified. In the most general terms, APRA (2010) views general provisions in the following terms:
"A general provision should be established to address latent losses known to exist in the credit portfolio but which cannot be ascribed to individual facilities. When creating and determining the level of general provisions, an ADI should consider the following:

(a) the general provision should not act as a substitute for the establishment of adequate specific provisions or the recording of an appropriate charge-off for bad debts;

(b) the general provision should be calculated in a prudent and conservative, but not excessive manner, so that it addresses an acceptable range of estimated losses; and

(c) the estimate of latent credit losses known to exist in the credit portfolio should reflect consideration of all significant factors that affect the collectibility of the credit portfolio as of the assessment date."

Due to its importance to the stability of the financial system, APRA is very vocal in stating that where it assesses that the level of general and/or specific provisions generated by an

Karamujic, H M (2010) 'An investigation into the fundamental drivers of pricing of residential mortgage products - A risk pricing viewpoint', Australasian Journal of Construction Economics and Building, 10 (4) 60-72 
ADI's own methodology is not adequately reflecting loss expectations in the credit portfolio, nor correctly measuring impaired assets, earnings or capital adequacy, it will discuss these concerns with the ADI. Following discussions between an ADI and APRA, the ADI may be required to adjust its level of general and/or specific provisions and/or amend its provisioning methodologies.

Notionally speaking, general provisioning can be catered for by using two methods, namely risk capital ${ }^{9}$ method and regulatory capital ${ }^{10}$ method. In its pure form the total of credit risk ${ }^{11}$, market risk ${ }^{12}$, operational risk ${ }^{13}$, interest rate risk in the banking book ${ }^{14}$ and business risk ${ }^{15}$ capital is referred to as "risk capital". Nevertheless, for the purposes of this paper, the risk capital represents a calculation of the capital required to act as a buffer against UL for credit, market and operational risks, at a prescribed minimum confidence level. Furthermore, to simplify the analysis and because the focus of our attention are home loans, for which the credit risk typically represents the largest risk, we assume that market and operational risks are not present. Consequently, the risk capital is equal to the credit risk capital. The total of risk capital plus pension risk ${ }^{16}$, dividends and intangibles ${ }^{17}$ capital is referred to as "Economic Capital".

According to the risk capital methodology, the UL amount is the loss of the worst-case scenario, more specifically, the difference between the worst-case scenario loss and the mean. To notionally illustrate the risk capital methodology let us use the same example as before i.e. assume home loans that lose, post recovery, 10 per cent once every ten years, and 0 per cent in the other nine years, within the same estimated risk exposure environment. As previously determined, the specific provision charge would be one per cent. Furthermore, if we are to assume that the lender is aiming to have a 100 per cent confidence interval, i.e. to be fully covered, it would need to cover for the 90 per cent interval of the residual gap between the worst-case scenario loss (10 per cent) and the mean loss (1 per cent). With the worst-case scenario loss being 10 per cent and the mean loss being one per cent, the UL amount would be 9 per cent. Consequently, the product level gross amount of risk capital required is 9 per cent multiplied by the outstanding loan amount.

In practice, the confidence interval is directly related to the lender's credit rating. For example, the National Australia Bank's (NAB's) current credit rating of AA implies that the bank-wide capital should go to a 99.97 per cent worst-case scenario, allowing a probability

\footnotetext{
${ }^{9}$ The term risk capital method is purposely used to differentiate from the regulatory capital method. Other commonly used, and probably more precise, term to depict this method is "calculation of the regulatory capital in accordance to the Basel II's internal ratings-based (IRB) approach".

10 Also known as "calculation of the regulatory capital in accordance to Basel I or the Basel II's standardized approach".

11 The risk arising from a borrower's failure to meet the term of any contract with the lender or otherwise fail to perform as agreed.

12 The risk arising from adverse market movement in the Trading Book which arises from money market dealing and position

${ }^{13}$ The risk of loss resulting from inadequate or failed internal processes, people and systems or from external events.

${ }^{14}$ The risk arising from adverse movements in interest rates on the structural interest rate position in the banking book.

${ }^{15}$ The risk to earnings and capital arising from the lender's exposure to potential operating losses following an unexpected reduction in revenue that cannot be offset by a corresponding timely decrease in expenses.

${ }^{16}$ The risk that assets are insufficient to meet the lender's legal and moral obligations to the current and former members of the relevant pension schemes.

17 In addition to capital to support the inherent risks, the applicable solvency standards require holding of sufficient capital to meet shareholder dividend payouts and intangibles such as unamortised goodwill, asset revaluation reserves, future income tax benefits and capitalised expenses.
}

Karamujic, H M (2010) 'An investigation into the fundamental drivers of pricing of residential mortgage products - A risk pricing viewpoint', Australasian Journal of Construction Economics and Building, 10 (4) 60-72 
of only 0.03 per cent of the historical worst-case scenario not being covered. In this view, capital represents the amount needed as a cushion against hard times.

Formally, the calculation of UL amount (also known as the gross risk capital amount $(\mathrm{GRCA})$ ) can be defined as the standard deviation of the default expectancy of a loan:

$$
\begin{gathered}
\mathrm{GRCA}=\mathrm{UL}=(\mathrm{EL} \times(\mathrm{LGD}-\mathrm{EL}))^{1 / 2} \\
\text { and } \\
\mathrm{EL}=\mathrm{PD} \times \mathrm{LGD}
\end{gathered}
$$

Thus, to calculate the UL amount for a single exposure ( $\left.U L_{a m t}\right)$ we use

$$
\mathrm{GRCA}_{\mathrm{amt}}=\mathrm{UL}_{\mathrm{amt}}=\mathrm{EAD} \times \mathrm{ULi}
$$

where $U L_{i}$ is the rate of $U L$ for a single exposure.

At a portfolio level, the calculation of UL portfolio amount $\left(U L_{p}\right)$ is conducted over the aggregated exposure, given the approach assumes a portfolio level PD. Thus:

$$
\mathrm{GRCA}_{p}=U \mathrm{~L}_{p}=E A D p \times U L_{p}
$$

Following calculation of portfolio-level $U L_{p}$, to calculate $U L$ for all portfolios $\left(U L_{p o}\right)$, we need to correlate $U L_{p}$ to the total lender's portfolio loan loss likelihood.

$$
\mathrm{GRCA}_{p o}=U L_{p o}=U L_{p} \times \sqrt{ } \text { Corr }
$$

Finally, the $\mathrm{GRCA}_{\mathrm{po}}$ at the required confidence level $\left(\mathrm{GRCA}_{\mathrm{rcl}}\right)$ is calculated by multiplying the correlated $U L_{p o}$ amount by the appropriate number of standard deviations of the required confidence level.

$$
\mathrm{GRCA}_{\mathrm{rcl}}=\mathrm{UL}_{\mathrm{po}} \times \mathrm{nsd},
$$

where $n_{s d}$ stands for number of standard deviations.

After deriving the GRCA, to get the net risk capital amount (NRCA) we need to subtract the capital benefit (the revenue earned from investing the allocated provisioning capital, as APRA allows limited usage of the allocated capital) amount from the GRCA. Finally, the risk capital charge amount (RCCA) equals the NRCA multiplied by the lender's hurdle rate ${ }^{18}$.

As previously indicated, an alternative way of calculating the UL amount is by using the regulatory capital method. The regulatory capital method aims to cater for the same reasons of capital adequacy as the risk capital method, however instead of primarily being determined by the lender's risk profile, it is set in isolation of the lender's risk profile by the regulatory authority, in Australia by APRA. In doing so, APRA arrives at the single minimum amount of capital the lender is required to hold, applicable to the particular lending class (such as the secured and unsecured lending classes). This minimum amount of capital is defined by the Capital Adequacy Accord, agreed to in 1988 (also known as Basel I). According to Basel I, the lender must hold capital that is no less than 8 per cent of riskweighted assets. Credit exposures are risk-weighted according to the three broad types of counterparty (government, banks and all others). The Accord specifies five general

\footnotetext{
${ }^{18}$ The hurdle rate can be defined as the minimum returns on regulatory or economic capital expected to be achieved to provide a sufficient return for the use of the lender's capital. Achieving returns equal to, or above, the hurdle rate means that shareholder value is being created.
} 
categories of risk weights: $0,10,20,50$ and 100 per cent. The sum of risk-weighted assets plus risk assessed from off balance-sheet business is then related to the lender's capital base. The resulting risk ratio is used as a measure of capital adequacy. In respect to the capital allowed to be used for the capital adequacy provision, for supervisory purposes, the allowed capital can be disaggregated into two tiers, namely Tier 1 (T1) and Tier 2 (T2) capital. T1 capital is comprised of the highest quality capital and includes: paid-up ordinary shares, non-repayable share premium accounts, general reserves, retained earnings, noncumulative irredeemable preference shares and minority interests in subsidiaries. On the other hand, T2 capital represents other capital, which falls short of some of the characteristics of the core capital. Based on differing degrees of permanence associated with the respective capital instruments, T2 capital can be divided into two further tranches. Upper T2 capital is comprised of general provision for doubtful debts, asset revaluation reserves, cumulative irredeemable preference shares, perpetual subordinated debt and mandatory convertible notes. Lower T2 capital is ranked behind upper T2 capital and entails limited life redeemable preference shares and term subordinated debt.

To calculate the gross regulatory capital amount (GRGCA) for a particular exposure we need to multiply the outstanding amount of the loan by at least 8 per cent, and adjust it with the applicable risk weighting. The net regulatory capital amount (NRGCA) is equal to the GRGCA less the capital benefit amount (the revenue earned from investing the allocated provisioning capital, as APRA allows limited usage of the allocated capital). Finally, to get the regulatory capital charge amount (RGCCA) we need to multiply the NRGCA by the lender's hurdle rate.

Ultimately, the total LLP charge (this amount is to be inputted into Equation (1)) entails the general provisioning (the UL cost charge, expressed as loan amount per centage of either RCCA or RGCCA) cost per-centage charge and the specific provisioning cost (EL) percentage charge. In closing, it is important to note that since home loans (being secured lending products) generally have better risk profile compared to other lending products, the risk capital method (being based on an internal assessment of risk) is the method most home lenders would prefer to use.

\section{Lender's Margin}

The lender's interest rate margin can be defined, in principle, as the difference between the interest rates on lenders' borrowings and their lending rates The lender's margin can be viewed as either gross or net margins. The gross margin is the difference between the COFs and the lending interest rate, and the net margin is the difference between the gross margin and all other costs that lenders face in developing, supporting and eventually closing the home loan.

\section{Other Costs}

Other costs, as presented in Equation (1), include the costs of sales (COS) and corporate overhead costs (COC). COS are comprised of home loan distribution, payment and processing costs. During the tenure of a home loan, lenders incur significant COC for activities such as general analysis, risk-related overview and analysis, etc. As a result, a portion of overall the COCs is distributed to various costs centres during the course of the year.

\section{A Simplified Example - the Cost plus Pricing Technique}

Let us now put all of that wonderful exposition into a simplified practical example, and look at recent history to see how the various components of the Cost plus Pricing technique (in particular LLP and COF) drove typical home loan interest rates at the time.

Karamujic, H M (2010) 'An investigation into the fundamental drivers of pricing of residential mortgage products - A risk pricing viewpoint', Australasian Journal of Construction Economics and Building, 10 (4) 60-72 


\begin{tabular}{|c|c|c|c|c|c|c|}
\hline (bps) - basis points & $\begin{array}{l}\text { June } \\
2004\end{array}$ & $\begin{array}{l}\text { June } \\
2005\end{array}$ & $\begin{array}{l}\text { June } \\
2006\end{array}$ & $\begin{array}{l}\text { June } \\
2007\end{array}$ & $\begin{array}{l}\text { June } \\
2008\end{array}$ & $\begin{array}{l}\text { June } \\
2009\end{array}$ \\
\hline Cost Of Funds (COF) ${ }^{1}$ & 549 & 566 & 596 & 642 & 781 & 325 \\
\hline Loan Loss Provision (LLP) $^{2}$ & 97 & 94 & 89 & 68 & 74 & 120 \\
\hline Lenders Margin (LM) $^{3}$ & 273 & 282 & 271 & 262 & 263 & 217 \\
\hline Cost Of Sales ( COS) ${ }^{4}$ & 5 & 5 & 5 & 5 & 5 & 5 \\
\hline $\begin{array}{l}\text { Corporate Overhead Costs } \\
\text { (COC) })^{4}\end{array}$ & 5 & 5 & 5 & 5 & 5 & 5 \\
\hline Interest Rate & 929 & 951 & 966 & 981 & 1,128 & 672 \\
\hline
\end{tabular}

Table 1: An Example - the Cost plus Pricing Technique

\section{Assumptions}

1. Represented by 90 days bank bills interest rate. Sourced from RBA (2010).

2. The total nominal lending provisions as a percentage of the total gross loans and advances. Sourced from APRA (2010b), Table 5.

3. The total nominal retained profits as a percentage of the total assets. Sourced from APRA (2010b), Table 5.

4. COS and COC are predominantly fix costs. They are estimated at 5 bps each across the observed period.

As shown in Table 1, the loan pricing landscape underwent some dramatic changes between 2004 and 2009. In particular:

(i) COF continued increasing until 2008 and then as a consequence of RBA's response to the GFC (from September 2008 to April 2009, the RBA reduced the cash rate by 4.25 per cent) experienced a significant fall,

(ii) LLPs continued falling until the emergence of the GFC (the market had largely forgotten about the concept of risk), which resulted in a sharp increase in provisioning (increased by 77 per cent, from June 2007 to June 2009), and

(iii) LMs were quite stable for the most of the observed period, with the exception of sizable fall recorded in 2009 as a consequence of the GFC (tightening of the wholesales markets forced funding costs up, while heightened risk aversion induced lenders to fight harder for lower risk opportunities).

\section{An Insight Into the Future}

As we look to the future, the price makeup will change again and may look as shown in Table 2.

\begin{tabular}{|c|c|c|c|}
\hline (bps) - basis points & November 2010 & June 2011 & June 2012 \\
\hline Cost Of Funds (COF) $^{\mathbf{1}}$ & 420 & 480 & 500 \\
\hline Loan Loss Provision (LLP) $^{2}$ & 110 & 110 & 100 \\
\hline Lenders Margin ( LM) $^{\mathbf{3}}$ & 210 & 250 & 270 \\
\hline Cost Of Sales ( COS) $^{4}$ & 5 & 5 & 5 \\
\hline Corporate Overheads ( COC) $^{4}$ & 5 & 5 & 5 \\
\hline Interest Rate $^{4}$ & $\mathbf{7 5 0}$ & $\mathbf{8 5 0}$ & $\mathbf{8 8 0}$ \\
\hline
\end{tabular}

Table 2: Possible Future Changes in Typical Mortgage Lending Interest Rate 
2. As financial markets stabilize and banking risk profiles improve, conservatively we expect provisioning cost to reduce by 10 bps in 2010, stay unchanged in 2011, and then also reduce by additional 10 bps in 2012 .

3. With stabilization of wholesale credit markets and ongoing improvement in domestic economic performance, lending margins are expected to improve. We forecasted for ongoing improvements during the observed period, and return to long run average by 2012.

4. COS and COC are predominantly fix costs. They are estimated at 5 bps each across the observed period.

Perhaps of most interest in gaining some insight into the future direction of interest rates is to look at which of the key drivers' discussed above are going to have prominent influences over the next few years. In regards to future movements in typical home loan interest rates we expect:

(i) a modest upward push driven by expected increase in COFs and LMs, and

(ii) partly offsetting downward push due to eventual reduction in LLPs.

\section{An Overview of Basel Capital Accords}

Main objectives of Basel Capital Accords are to promote safety and soundness in the financial institutions by ensuring maintenance of sufficient capital levels, supporting development and implementation of adequate policies and processes, and ensure continuance of robust governance practices to safeguard against all types of risk. The name 'Basel' comes from the Swiss city of Basel, which is where the Bank for International Settlements (BIS) developed the original framework, known as Basel I.

Principally, the development of Basel I came about in response to concerns by bank regulators that some banks, especially internationally active banks, did not properly understand risk and thus posed a systemic risk to the global banking system. The Accord was initially intended to only apply to banks in the world's richest ten countries, nevertheless the Accord was eventually adopted by almost every country in the world.

In short, Basel I aimed to ensure a standard level of banking safety and security by requiring institutions to have sufficient capital to cover their risks. The Accord was introduced in 1988 and is also known as the Capital Adequacy Accord of 1988. It prescribes the holding of core T1 of no less than 4 per cent of risk-weighted assets (with common equity (CE), also known as core T1 capital ratio, of 2 per cent), and total regulatory capital (TRC) of no less than 8 per cent of risk-weighted assets ${ }^{19}$. Major critiques of Basel I are that it focus on credit risk and that the bulk of a bank's assets are subject to the same capital charges, no matter how risky they are.

As the international financial system has grown more sophisticated and complex, the initial Accord's focus on credit risk has become insufficient. Subsequent events led to a recognition that more sophisticated standards are required to take into account industry advances and, as a result, the BIS began to review the Basel I framework. The regime was refined and made more sophisticated, and the risk weightings more granular, in 2004 with Basel II. For example, it allowed banks with the appropriate systems and historical data to use an internal ratings-based (IRB) approach to assess the risks of a particular lending ${ }^{20}$. On the other hand, the Basel Il's standardised approach continued using Basel I practice of setting specific risk weights for certain types of credit risk. The risk weight categories prescribed under the standardised approach are the same as those used under Basel 1 with an addition of new $150 \%$ rating, which is allocated for borrowers with poor credit ratings.

\footnotetext{
${ }^{19}$ Applicable risk weight are: $0 \%$ for short term government bonds, $20 \%$ for exposures to the Organisation for Economic Co-operation and Development (OECD) member countries' banks, 50\% for residential mortgages and $100 \%$ weighting on other personal and unsecured commercial loans.

20 The Basel II Accord comprises of three interrelated segments that are known as the "three pillars". For more on the three Basel II pillars and different Basel II approaches see BIS (2006).
}

Karamujic, H M (2010) 'An investigation into the fundamental drivers of pricing of residential mortgage products - A risk pricing viewpoint', Australasian Journal of Construction Economics and Building, 10 (4) 60-72 
The overall objective of the Basel II was to promote safety and soundness in financial institutions by ensuring the maintenance of sufficient capital levels, along with supporting policies and processes and robust governance practices to safeguard against credit, operational, market and interest rate risks. By allowing lenders to match their capital to the level of risk, the Basel II led to more pragmatic and competitive pricing outcomes.

Nevertheless, over time it became obvious that Basel II has several major shortcomings, namely: (i) it became an international competition for consultants: how to help banks allocate less capital, (ii) it was accused of boosting procyclicality of the banking industry21, (iii) it created significant incentives for banks to move risky assets to unregulated parts of the holding company, and (iii) banks took advantage of the opportunity to transfer risk to investors - use securitization22.

The analytical portion of the paper focuses on the two presently established accords: Basel I and Basel II. Those regulatory frameworks represent decades-long effort at perfecting minimum capital requirements calculations. Unfortunately, as recent events clearly indicate, those rules have not proved as useful in preventing bank illiquidity as a result of the GFC. For example, just five days before the bankruptcy of Lehman Brothers in September 2008, it boasted a Basel-type T1 capital ratio of 11 per cent; significantly above the regulatory minimum. When the share price collapsed, counter-party confidence ebbed away much faster than the capital adequacy ratio would suggest.

At its 12 September 2010 meeting, the Group of Governors and Heads of Supervision, the oversight body of the Basel Committee on Banking Supervision, announced a substantial strengthening of existing capital requirements. This proposal has been dubbed "Basel III". According to the Basel III proposal, the total risk capital (TRC) can be presented as:

$$
\mathrm{TRC}=\mathrm{T} 1+\mathrm{T} 2+\mathrm{CB}+\mathrm{CCB}+\mathrm{CSIB}
$$

where T1 represents Tier 1 capital, T2 represents Tier 2 capital, CB represents capital conservation buffer, CCB represents countercyclical capital buffer, and CSIB represents capital for systemically important banks. On the other hand, the T1 is comprised of common equity (CE) and other T1 (OT1).

$$
\mathrm{T} 1=\mathrm{CE}+\mathrm{OT} 1
$$

Possibly the most important change that comes with Basel III is setting of much stricter minimum standards for CE. Something similar did exist in the past, but it was set very low, at just 2 per cent. Compared to Basel I and Basel II, according to Basel III, CE is the main thing that matters. Furthermore, various dubious things which currently count as T1 or T2 capital, but should not, will be phased out over a period of 10 years, beginning in 2013. According to the proposal, the minimum requirement for CE is 4.5 per cent, for OT1 is 1.5 per cent and for T2 is 2 per cent. On the whole, the new standards for CE are significantly tougher than the old standards for T1 capital in total.

In addition to strengthening CE requirements, there is a CB of another 2.5 per cent. Most, if not all banks, should strive to be well above that buffer. If there's some kind of crisis and banks are forced to write down a lot of bad loans, they can eat into the buffer. That will bring extra regulatory oversight, and those banks won't be able to pay dividends. Assuming full allocation of CE, banks will need to have 7 per cent CE, 1.5 per cent OT1, and 2 per cent T2, i.e. 10.5 per cent TRC.

21 For more see Imad (2010), and Gordy and Howells (2004).

22 To see how it functioned in Ireland see Coates (2008).

Karamujic, H M (2010) 'An investigation into the fundamental drivers of pricing of residential mortgage products - A risk pricing viewpoint', Australasian Journal of Construction Economics and Building, 10 (4) 60-72 
Furthermore, when credit in an economy is growing faster than the economy itself, a CCB comes in play. Principally, CCB requires banks to hold more capital in good times. This countercyclical capital framework is intended to contribute to a more stable banking system, which will help dampen economic and financial shocks. That countercyclical buffer won't be set by the BIS; it will be left up to national regulators. According to preliminary comments made in media, one can probably expect OECD countries to enforce it up to the maximum of 2.5 per cent. In view of that when the economy's is doing well, banks are going to need 9.5 per cent CE, 1.5 per cent OT1, and 2 per cent T2, i.e. 13 per cent TRC.

Finally, according to BIS (2010) "Systemically important banks should have loss absorbing capacity beyond the standards announced...". It still not know how high CSIB will be, but the chances are that when an announcement comes, the biggest banks are going to need significantly more capital. Work continues on this issue in the BIS's Financial Stability Board and relevant Basel Committee work streams.

It is important to note that the above outlined impacts will not be implemented immediately, instead the standards start being phased in on January 1,2013, with a CE requirement of 3.5 per cent. That rises to the final 4.5 per cent in 2015 . Other parts of the structure take longer, but they're all phased in by January 1, 2019.

With respect to commenting on the proposal, at least at this early stage, the following statements made by the ATCA (2010) make a lot of sense "...the fact that the proposals are dubbed Basel III suggests that regulators have been here twice before! The record of bankcapital rules is crushingly bad in the wake of new types of securitisation instruments, excessive risk taking, self-measurement of risk and financial markets' volatility... In the days when banks could not rely on governments to save them, they carried huge capital buffers to protect themselves against losses and drops in confidence. In the late 19th century a typical American or European bank had an equity buffer, i.e. core capital, equivalent to $15-25 \%$ of its assets! As recently as the 1960s British banks held more than a quarter of their assets in low-risk, liquid form, such as cash or government bonds. Are we in the end -- if not via Basel III then Basel IV -- likely to return to 19th century levels of capital adequacy? This would no doubt have significant consequences for the valuation of banks and the unencumbered survival of large capital financial institutions."

\section{Conclusion}

The purpose of this paper has been to expound how, in practice, lenders price their home loans, i.e. how they determine their home loan interest rates. The paper started by outlining the importance of home loan pricing, its major components and objectives. The cost plus pricing technique was then examined. Particular attention was given to the cost plus pricing technique because it is the basis for all other pricing techniques i.e. all other pricing techniques only focus on different margin (mark-up) combinations. Having gone through a rather detailed discussion of how contemporary lenders identify and quantify risks, the inevitable conclusion is that a lot that has been outlined, with some modifications, can also be used to enhance the ways other disciplines, such as construction and property, assess, quantify and price their risks. Due to a number of references made to it while discussing LLP, the paper provided an overview of Basel capital accords. Given the debates about the housing market that have been raging since the GFC, the eventual impacts of the proposed Basel III, as the newly proposed measures are phased in, will be very closely monitored. After more information becomes available, an interesting possibility for further research would be to assess the impact of the implementation of Basel III on LLP costs and home loan interest rates. Overall, the author hopes that the paper will help demystify the underlying elements of the pricing calculations (such as COFs and LLPs) and the ways in which these elements relate to each other. Consequently, the paper should also contribute towards better understanding of the likelihood and probability of future changes in home loan interest rates.

Karamujic, H M (2010) 'An investigation into the fundamental drivers of pricing of residential mortgage products - A risk pricing viewpoint', Australasian Journal of Construction Economics and Building, 10 (4) 60-72 


\section{References}

APRA (2010) Prudential Standards and Guidance Notes for ADIs, http://www.apra.gov.au/ADI/Prudential-Standards-and-Guidance-Notes-for-ADIs.cfm, viewed January 2010

APRA (2010a) Prudential Standard APS 113, http://www.apra.gov.au/ADI/PrudentialStandards-and-Guidance-Notes-for- $\quad$ http://www.apra.gov.au/Policy/upload/Draft-APS-1132006.pdf, viewed January 2010

APRA (2010b) Quarterly Bank Performance, September 2009 (revised 26 March 2010), http://www.apra.gov.au/Statistics/ADI-Quarterly-Performance-Statistics.cfm, viewed May 2010

ATCA (2010) Basel III: Making Banks Stronger or Not? http://www.mi2g.com/ $\mathrm{cgi} / \mathrm{mi}$ g $/$ frameset. php?pageid=http\%3A/www.mi2g.com/cgi/mi2g/press $/ 250110 . \mathrm{php}$, viewed September 2010

BIS (1988) Basel I (1988) - Basel Committee: International convergence of capital measurement and capital standards (updated to April 1998), http://www.bis.org/publ/bcbsc111.htm, viewed January 2010

BIS (2006) Basel II: Revised international capital framework, http://www.bis.org/publ/bcbsca.htm, viewed February 2010

BIS (2010) Press release - Group of Governors and Heads of Supervision announces higher global minimum capital standards, http://www.bis.org/press/p100912.htm, viewed September 2010

Business Banking Board (2002) Pricing Strategies, Corporate Executive Board, July

Coates, D. (2008) The Irish Sub-prime Residential Mortgage Sector: International Lessons for an Emerging Market, Journal of Housing and the Built Environment, 23, 131-144

Council on Financial Competition (1997) Beyond Commodity Status, Corporate Executive Board

Council on Financial Competition (2003) Mortgage Pricing Practices, Corporate Executive Board, July

Council on Financial Competition (2005) Strategic International Trends, Corporate Executive Board, February

Council on Financial Competition (2006) Innovations in the Mortgage Market, Corporate Executive Board, July

Ellis, L. (2009) The Global Financial Crisis: Causes, Consequences and Countermeasures, http://www.rba.gov.au/speeches/2009/sp-so-150409.htm, viewed May 2010

Gordy, M. B. and Howells, B. (2004) Procyclicality in Basel II: Can We Treat the Disease Without Killing the Patient?, Board of Governors of the Federal Reserve System,http://www.bis.org/bcbs/events/rtf04gordy_howells.pdf, viewed September 2010

Imad, A. M. (2010) Basel II as a Casualty of the Global Financial Crisis, Journal of Banking Regulation 11, 95-114

Karamujic, M. H. (2009) The Determination of Home Loan Interest Rates and an Empirical Assessment of their Cyclicality and Seasonality in Australia, Saarbrucken Germany: VDM

Kosonen, K. (1997) The Pricing of Subsidized Housing Loans in Finland, Journal of Housing and the Built Environment, 12 (4), 381-399

Moody's (2010) Moody's Rating Process - Introduction, http://v3.moodys.com/ Pages/default_au.aspx, viewed May 2010

RBA (2010) Interest Rates and Yields - Money Market, April 2010, http://www.rba.gov.au/statistics/tables, viewed May 2010 